\title{
ŹRÓDŁA POWODZENIA MAŁYCH I ŚREDNICH PRZEDSIĘBIORSTW W BRANŻY BIOTECHNOLOGICZNEJ
}

\author{
Anna Adamik \\ Politechnika Łódzka
}

\begin{abstract}
Abstrakt
W artykule podjęto próbę identyfikacji kluczowych parametrów oraz źródeł skuteczności polskich firm biotechnologicznych. Ponieważ ponad $90 \% \mathrm{z}$ nich to przedsiębiorstwa małe i średnie, bazą do analiz jest profil charakteryzujący tego typu organizacje. W opracowaniu nałożono na niego profil firm branży biotechnologicznej. W wyniku zestawienia tych dwóch bloków informacji ustalono główne źródła sukcesu i problemów firm $\mathrm{w}$ branży biotechnologicznej oraz wynikające $\mathrm{z}$ nich wnioski. W celu zweryfikowania analiz literaturowych empiria, badaniu metodą opisu przypadków poddano dwie typowe dla branży małe firmy biotechnologiczne.
\end{abstract}

\section{Wprowadzenie}

Branża biotechnologiczna uznawana jest $\mathrm{w}$ ostatnich latach za jedną z najbardziej innowacyjnych, a przez to kluczowych dla rozwoju kraju, dziedzin gospodarki. Kwalifikując się do szeroko pojętego sektora wysokich technologii, jest wyznacznikiem nowoczesności i konkurencyjności oraz determinantą osiaganego w kraju wzrostu gospodarczego [Turowski, 2005]. Badania dowodzą, że kraj, który nie jest $\mathrm{W}$ stanie przeprowadzić odpowiedniej restrukturyzacji w kierunku zwiększenia udziału opierających się na innowacjach branż wysokiej techniki, skazuje się na zacofanie i powiększanie się luki technologicznej pomiędzy nim a pozostałymi krajami [Zakrzewska-Bielawska, 2011]. Aby do takich krajów nie klasyfikowano Polski, warto poddać bliższym analizom specyfikę branży oraz parametry charakteryzujące polskie firmy biotechnologiczne. Działania te zasygnalizują stan i kierunki niezbędnych zmian, zarówno dotyczących rozwoju przedsiębiorstw, jak i polityki państwa w tym zakresie.

Celem opracowania będzie identyfikacja kluczowych parametrów oraz źródeł skuteczności polskich firm biotechnologicznych. Ponieważ ponad $90 \%$ z nich to przedsiębiorstwa małe i średnie, bazą analiz będzie ustalenie profilu charakteryzującego tego typu organizacje. Następnie na profil ten 
nałożony zostanie profil firm branży biotechnologicznej. W wyniku zestawienia tych dwóch bloków informacji zostaną ustalone główne źródła sukcesu i problemów firm z branży biotechnologicznej oraz wynikające $\mathrm{z}$ nich wnioski. W celu zweryfikowania analiz literaturowych empiria, badaniu metodą opisu przypadków poddane zostaną dwie typowe dla branży, małe firmy biotechnologiczne.

\section{Specyfika branży biotechnologicznej - tlo analiz}

Branża biotechnologiczna to jedna $\mathrm{z}$ branż sektora wysokich technologii. Według dziedzinowego podejścia OECD do branż tego sektora należą: przemysł statków powietrznych i kosmicznych, produkcja maszyn biurowych i komputerów, produkcja sprzętu RTV, przemysł farmaceutyczny, a według klasyfikacji z 2005 roku również instrumenty medyczne, optyczne i precyzyjne [Wojnicka, 2006]. Przy podejściu horyzontalnym, uwzględniającym perspektywę nauki oraz zakres komercyjnych zastosowań, promuje się dodatkowo technologie, które stają się bazą dla zupełnie nowej infrastruktury ekonomicznej, zorientowane na długookresowy i wielotorowy rozwój. Uwzględnić w badanym sektorze można wówczas np. branżę informacyjną, komunikacyjną, inżynierię materiałową, mikroelektronikę oraz biotechnologię [Brodzicki, 2002].

Biotechnologia silnie związana jest z przemysłem farmaceutycznym, przez co jest obecnie jedną $\mathrm{z}$ bardziej naukochłonnych branż. Ponieważ w najszerszym ujęciu obejmuje ona nie tylko nowoczesną biotechnologię, ale również tradycyjne rodzaje działalności oraz te znajdujące się na granicy przedmiotu tego sektora, najogólniej biotechnologię można zdefiniować jako ,interdyscyplinarną dziedzinę nauki i techniki zajmującą się zmianą materii żywej i nieożywionej poprzez wykorzystanie organizmów żywych, ich części, bądź pochodzących od nich produktów, a także modeli procesów biologicznych w celu tworzenia wiedzy, dóbr i usług" [Ministerstwo Nauki i Szkolnictwa Wyższego, 2007]. W związku z takim ujęciem biotechnologii towarzyszą: innowacyjność, złożoność, wysokie koszty rozwoju produktów oraz realizowanych procesów i technologii. $Z$ perspektywy pojedynczych firm wyklucza to coraz częściej samodzielne projektowanie i wdrażanie produktów i procesów, gdyż niemożliwe jest perfekcyjne zrozumienie oraz sfinansowanie zbyt wielu, a przy tym tak wysoko zaawansowanych technologicznie aspektów i detali produkcyjno-organizacyjnych przez pojedynczego eksperta czy nawet pojedynczą organizację.

Firmy branży biotechnologicznej zwykle więc, dla skutecznego zrealizowania stawianych przed nimi celów, działają w oparciu 
o różnorakie sieci powiązań i umów o współpracy. Najsprawniejsze w ich praktyce okazuje się realizowanie związków współpracy, które lączą elastyczność i inicjatywę małych firm oraz zdolności inżynierskie i marketingowe dużych organizacji (w tym ze sfery naukowo-badawczej i agencji rządowych). Sieci te mają zwykle dynamiczny charakter, integrują wiele firm o nieprzeciętnych umiejętnościach, które systematycznie wspólnie realizują proces uczenia się. Najczęściej do takich sieci należy kilkanaście firm produkcyjnych i usługowych, różne agencje rządowe, a także organizacje sektora non-profit, takie jak np. uniwersytety. Interakcje między tymi organizacjami, ich wzajemność, otwartość, partnerskość i odpowiedzialność, umożliwiają szybszą dyfuzję wiedzy i innowacji oraz szybsze dostosowywanie systemu społecznego do realizowanych przez nie zmian technologicznych. Uczenie i dostosowywanie się jest tym szybsze, im większe jest uczestnictwo firm w sieciach współpracy (większy dostęp do wiedzy) oraz im większe są zdolności firmy do użytkowania tej wiedzy i tworzenia na jej podstawie nowych rozwiązań (większe zdolności absorpcyjne). Zależy to $\mathrm{w}$ znacznym stopniu od wybranej formy współpracy. Firmy sektora wysokich technologii stosują, w zależności od swojej aktywności i zasobów organizacyjnych, szerokie ich spektrum - od luźnych porozumień o współpracy, umów dżentelmeńskich, poprzez umowy OEM (Original Equipment Manufacturing), podzlecanie (subcontracting), franszyzę (franchising), joint ventures, wzajemną wymianę lub wykup udziałów (cross sparing), do wirtualnego przedsiębiorstwa; od porozumień krótkotrwałych do długofalowych. Porozumienia te mogą również przyjąć postać partnerstwa czy aliansu strategicznego [Adamik, 2007].

Branża biotechnologiczna ze względu na swoją rozbudowaną specyfikę została podzielona przez EuropaBio (stowarzyszenie 24 biotechnologicznych organizacji narodowych) na cztery kluczowe obszary [Ministerstwo Nauki i Szkolnictwa Wyższego, 2007]:

1) biotechnologię białą - jest to biotechnologia przemysłowa wykorzystująca systemy biologiczne $\mathrm{w}$ produkcji przemysłowej i ochronie środowiska; opiera się ona na biokatalizie i bioprocesach;

2) biotechnologię czerwoną - jest to biotechnologia wykorzystywana $\mathrm{w}$ ochronie zdrowia, w szczególności w zakresie produkcji nowych biofarmaceutyków, rozwoju diagnostyki genetycznej czy genoterapii i ksenotransplantologii;

3) biotechnologię zieloną - jest to biotechnologia związana z rolnictwem, obejmująca stosowanie metod inżynierii genetycznej w celu doskonalenia produkcji roślinnej czy zwierzęcej; 
4) biotechnologię fioletową - jest to biotechnologia związana z ustawodawstwem, które dotyczy biotechnologii (prawne i społeczne uwarunkowania).

Spośród czterech ogólnie wyodrębnionych segmentów rynku biotechnologicznego w Polsce 50\% rynku stanowi biotechnologia stosowana $\mathrm{w}$ medycynie, $30 \% \mathrm{w}$ przemyśle, a $15 \% \mathrm{w}$ rolnictwie i działalności związanej ze środowiskiem naturalnym [PMR, 2011]. Blisko $33 \%$ przedsiębiorstw farmaceutycznych i biotechnologicznych ma swoja siedzibę na terenie województwa mazowieckiego. Według danych GUS, na koniec III kwartału 2011 r. w Polsce istniało 687 podmiotów działających w branży produkcji wyrobów farmaceutycznych (w tym leków) oraz zajmujących się badaniami biotechnologicznymi. W pierwszej grupie działały 532 przedsiębiorstwa (stanowiące 77\% wyszczególnionej grupy), z których 182 zajmowało się wytwarzaniem podstawowych substancji farmaceutycznych, a 350 produkcją leków oraz pozostałych wyrobów farmaceutycznych. Działalność związaną z badaniami biotechnologicznymi prowadziło 155 podmiotów (23\% wyszczególnionych podmiotów). Segment ten stanowił $6 \%$ wszystkich podmiotów prowadzących działalność związaną z badaniami naukowymi. Pod względem wielkości, łącznie w branży farmaceutycznej i biotechnologicznej, dominowały mikroprzedsiębiorstwa, w których zatrudnionych było nie więcej niż 9 osób (80\% wszystkich podmiotów), firm małych - zatrudniających od 10 do 49 osób - było około $\mathbf{1 0 \%}$, średnich 7\%, a dużych zatrudniających powyżej 250 osób $-\mathbf{3 , 6 \%}$ ogółu [Podlaskie Obserwatorium Rynku Pracy i Prognoz Gospodarczych, 2011].

Branża ta, ze względu na swoją rolę $w$ gospodarce i strukturę podmiotową, jest jedną $\mathrm{z}$ branż priorytetowych, w szczególny sposób wspieranych przez polski rząd [Sektor farmaceutyczny i biotechnologiczny w Polsce, 2011].

\section{Profil małych i średnich przedsiębiorstw a specyfika działania w branży biotechnologicznej}

Dokonując analizy branży biotechnologicznej, należy uwzględnić i podkreślić fakt, iż ponad $90 \%$ firm branży to przedsiębiorstwa zaliczane do MSP. Ich stan i rozwój uznawany jest, podobnie jak w sygnalizowanym wcześniej przypadku sektora wysokich technologii, za kolejną z miar wzrostu gospodarczego oraz zdrowej konkurencji rynkowej. $\mathrm{Z}$ racji swojej roli $\mathrm{w}$ gospodarce jest on szczegółowo i coraz powszechniej badany i opisywany w literaturze. Charakteryzują go zróżnicowane, specyficzne 
kryteria, zarówno ilościowe ${ }^{17}$, jak i jakościowe ${ }^{18}$. Uwzględniając wybrane, najczęściej dostrzegane parametry MSP, sporządzono profil charakterologiczny standardowej firmy tego sektora (kolumna $2 \mathrm{w}$ tabeli 1 ). Zestawiając go z profilem przeciętnej firmy branży biotechnologicznej (kolumna 3 w tabeli 1), ustalono, co ze specyfiki MSP wspiera rozwój przedsiębiorstw $\mathrm{z}$ analizowanej branży (kolumna 4 tabeli 1). Analizę porównawczą profili zawiera tabela 1 .

Tabela 1.Źródła sukcesu MSP w biotechnologii

\begin{tabular}{|c|c|c|c|}
\hline \multirow[b]{2}{*}{ Parametry } & \multicolumn{3}{|c|}{ Profile } \\
\hline & \begin{tabular}{l}
\multicolumn{1}{c}{ MSP } \\
[Matejun, 2012; \\
Sektor matych i \\
średnich \\
przedsiębiorstw \\
w Polsce, 2012; \\
Łuczka, 2001; \\
Dominiak, 2005; \\
Wasilczuk, 2005; \\
Janiuk, 2004; Safin, \\
2008; Lachiewicz, \\
Załęczny, 2003; \\
Piasecki, 2001; \\
Nogalski, Karpacz, \\
Wójcik-Karpacz, \\
2004]
\end{tabular} & \begin{tabular}{l}
\multicolumn{1}{c}{ Firm branży } \\
biotechnologicznej \\
[PMR, 2011; Sektor \\
farmaceutyczny \\
i biotechnologiczny \\
w Polsce, 2011; Podlaskie \\
Obserwatorium Rynku \\
Pracy i Prognoz \\
Gospodarczych, 2011; \\
Wojnicka, 2006; Główny \\
Urząd Statystyczny, \\
2011; portal \\
Biotechnologia.com, \\
2011; Ustawa \\
refundacyjna..., 2011; \\
portal \\
dolinabiotechnologiczna. \\
p, 2011; OECD, 2009; \\
Zakrzewska-Bielawska, \\
2011]
\end{tabular} & $\begin{array}{c}\text { Cecha MSP } \\
\text { przydatna } \\
\text { w branży } \\
\text { biotechnologicznej }\end{array}$ \\
\hline $\begin{array}{l}\text { Funkcje } \\
\text { zarządzania }\end{array}$ & $\begin{array}{l}\text { Pełni przedsiębiorca- } \\
\text { właściciel, który } \\
\text { bardzo często } \\
\text { dominuje i swoją }\end{array}$ & $\begin{array}{l}\text { W większości tak jak } \\
\text { w MSP, gdyż ok. } 90 \% \\
\text { sektora to firmy mikro } \\
\text { i małe, a } 7 \% \text { to firmy }\end{array}$ & $\begin{array}{l}\text { Osoba } \\
\text { determinująca } \\
\text { rozwój (np. } \\
\text { właściciel), jej }\end{array}$ \\
\hline
\end{tabular}

${ }^{17}$ Liczba zatrudnionych w przeliczeniu na pełne etaty; wielkości finansowe np.: poziom obrotów, przychodów, wyniku finansowego firmy; wartość aktywów, pasywów; wartość środków trwałych; udział kapitału trwałego w przedsięwzięciu; wartości rynkowe: udział w rynku sprzedaży; liczba odbiorców; wielkość lub wartość produkcji; zasięg działania rynkowego.

${ }^{18} \mathrm{Na}$ przykład finansowa niezależność, rodzaj własności, sposób zarządzania, struktura prawno-organizacyjna, gospodarka finansowa itp. 


\begin{tabular}{|c|c|c|c|}
\hline . & 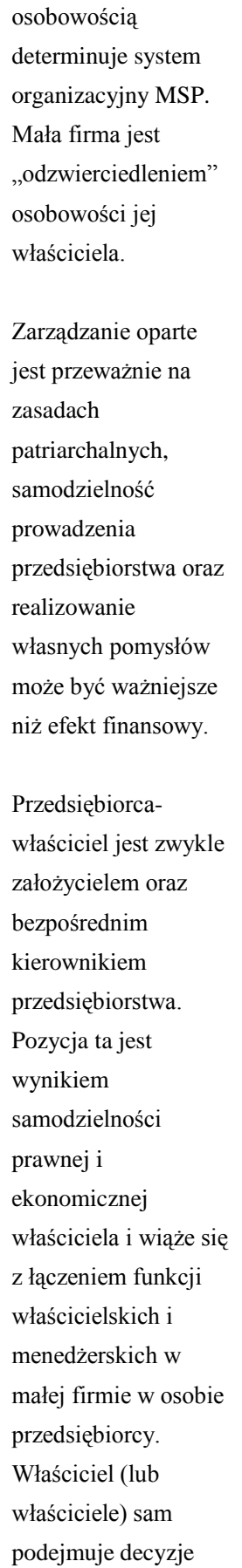 & $\begin{array}{l}\text { średnie. } \\
\text { Właściciel zwykle } \\
\text { posiada doświadczenie } \\
\text { i wykształcenie } \\
\text { kierunkowe, dzięki czemu } \\
\text { często ma pasję i wizję } \\
\text { tego, w jakim kierunku } \\
\text { rozwijać profil } \\
\text { działalności firmy. } \\
\text { W firmach dużych, } \\
\text { instytutach i uczelniach, } \\
\text { gdzie zarządzaniem } \\
\text { zajmują się zatrudnieni } \\
\text { menedżerowie. } \\
\text { Podejmowanie decyzji na } \\
\text { podstawie danych } \\
\text { empirycznych. } \\
\text { Kierowanie }\end{array}$ & $\begin{array}{l}\text { doświadczenie, } \\
\text { wykształcenie } \\
\text { kierunkowe, pasja } \\
\text { i wizja }\end{array}$ \\
\hline
\end{tabular}




\begin{tabular}{|c|c|c|c|}
\hline & $\begin{array}{l}\text { ważne dla firmy, bez } \\
\text { wsparcia opinii } \\
\text { zespołów doradczych. }\end{array}$ & & \\
\hline $\begin{array}{l}\text { Wiedza z zakresu } \\
\text { kierowania } \\
\text { przedsiębiorstwe } \\
\text { m }\end{array}$ & $\begin{array}{l}\text { Relatywnie niski } \\
\text { poziom wykształcenia } \\
\text { kadry w zakresie } \\
\text { zarządzania, wiedza } \\
\text { z zarządzania często } \\
\text { niewystarczająca. } \\
\text { Funkcjonowanie } \\
\text { kierownictwa na } \\
\text { zasadzie ,straży } \\
\text { pożarnej”, często na } \\
\text { podstawie własnej } \\
\text { intuicji, a nie oparte } \\
\text { na przyjętej strategii } \\
\text { rozwoju i strategiach } \\
\text { cząstkowych. } \\
\text { Przewaga decyzji } \\
\text { operacyjnych, a nie } \\
\text { strategicznych. Brak } \\
\text { sformalizowanej } \\
\text { strategii działania. }\end{array}$ & $\begin{array}{l}\text { W większości tak jak } \\
\text { w MSP, gdyż ponad 90\% } \\
\text { sektora to firmy mikro, } \\
\text { małe i średnie. Choć } \\
\text { w firmach tych spotkać } \\
\text { można stosunkowo duży } \\
\text { odsetek osób z } \\
\text { wykształceniem } \\
\text { wyższym, to jednak w } \\
\text { większości jest to } \\
\text { wykształcenie związane } \\
\text { z branżą, a nie } \\
\text { z zarządzaniem. } \\
\text { Inaczej w firmach } \\
\text { dużych, instytutach i } \\
\text { uczelniach, gdzie } \\
\text { zarządzaniem zajmują się } \\
\text { zatrudnieni do tego, } \\
\text { profesjonalnie } \\
\text { przygotowani } \\
\text { menedżerowie, często też } \\
\text { różnego typu organy } \\
\text { kolegialne. }\end{array}$ & - \\
\hline $\begin{array}{l}\text { Samodzielność } \\
\text { dzialania }\end{array}$ & $\begin{array}{l}\text { Samodzielność } \\
\text { prawna i ekonomiczna } \\
\text { skupiona jest w } \\
\text { rękach właściciela } \\
\text { (ewentualnie } \\
\text { niewielkiej liczby } \\
\text { właścicieli) oraz jego } \\
\text { rodziny. } \\
\text { Samodzielność ta } \\
\text { wyraża się poprzez } \\
\text { możliwość realizacji } \\
\text { przez przedsiębiorcę }\end{array}$ & $\begin{array}{l}\text { Duże ograniczenia } \\
\text { w działaniu firm tego } \\
\text { sektora ze względu na } \\
\text { regulacje prawne z } \\
\text { zakresu dopuszczenia do } \\
\text { obrotu produktów sektora } \\
\text { biotechnologicznego. } \\
\text { Uregulowania prawne są } \\
\text { szczególnie ważne w } \\
\text { przypadku produktów } \\
\text { biotechnologicznych } \\
\text { mających bezpośredni } \\
\text { wpływ na zdrowie i życie }\end{array}$ & - \\
\hline
\end{tabular}




\begin{tabular}{|c|c|c|c|}
\hline & $\begin{array}{l}\text { MSP) } \\
\text { Niewielki zakres lub } \\
\text { wręcz brak } \\
\text { możliwości } \\
\text { pozyskania źródeł } \\
\text { finansowania } \\
\text { właściwych dla rynku } \\
\text { kapitałowego. } \\
\text { Niska zdolność } \\
\text { kredytowa. } \\
\text { Możliwość wsparcia } \\
\text { działań rozwojowych } \\
\text { ze środków } \\
\text { publicznych i UE } \\
\text { (różnego typu } \\
\text { programy pomocowe). }\end{array}$ & $\begin{array}{l}\text { regionalne programy } \\
\text { operacyjne. } \\
\text { Firmy starają się } \\
\text { pozyskać jako wsparcie } \\
\text { swoich działań środki } \\
\text { budżetowe, środki z UE, } \\
\text { pomoc organizacji } \\
\text { międzynarodowych } \\
\text { i instytucji zagranicznych, } \\
\text { innych przedsiębiorstw, } \\
\text { placówek PAN, szkół } \\
\text { wyższych, np. program } \\
\text { wspierania infrastruktury } \\
\text { badawczej MNiSW. }\end{array}$ & \\
\hline $\begin{array}{l}\text { Wyposażenie } \\
\text { w zasoby }\end{array}$ & $\begin{array}{l}\text { Słabe wyposażenie } \\
\text { w kapitał finansowy } \\
\text { i rzeczowy. } \\
\text { System zaopatrzenia } \\
\text { materialnego oparty } \\
\text { na zamówieniach, } \\
\text { z wyjątkiem sfery } \\
\text { handlu. }\end{array}$ & $\begin{array}{l}\text { Wyposażenie w zasoby } \\
\text { materialne i niematerialne } \\
\text { obarczone wysokim } \\
\text { ryzykiem. Technologie } \\
\text { zawarte w patentach } \\
\text { i licencjach. Ważny jest } \\
\text { dostęp do właściwych } \\
\text { technologii. Niezbędne } \\
\text { nowoczesne zaplecze } \\
\text { naukowo-badawcze oraz } \\
\text { dostęp do aparatury } \\
\text { badawczej. } \\
\text { Trudny dostęp do } \\
\text { zakupów ze względu np. } \\
\text { na procedury } \\
\text { i scentralizowane zakupy, } \\
\text { niezbyt rozbudowany } \\
\text { rynek dostawców - dużo } \\
\text { koncernów światowych. } \\
\text { Wysokie koszty zmiany } \\
\text { dostawcy. }\end{array}$ & - \\
\hline
\end{tabular}




\begin{tabular}{|c|c|c|c|}
\hline & $\begin{array}{l}\text { własnych pomysłów } \\
\text { oraz realizacji funkcji } \\
\text { kierowniczych, które } \\
\text { są wykonywane na } \\
\text { własne ryzyko. Poza } \\
\text { tym to także oznaka } \\
\text { niezależności firmy od } \\
\text { innych podmiotów. }\end{array}$ & $\begin{array}{l}\text { ludzkie. } \\
\text { Samodzielność firm } \\
\text { sektora ogranicza także } \\
\text { penetrowanie rynku przez } \\
\text { duże, międzynarodowe } \\
\text { korporacje w } \\
\text { poszukiwaniu nowych } \\
\text { rozwiązań, patentów i ich } \\
\text { wykupywanie. Taka } \\
\text { działalność pogłębia } \\
\text { koncentrację podmiotów } \\
\text { w sektorze } \\
\text { biotechnologii. }\end{array}$ & \\
\hline $\begin{array}{l}\text { Gospodarka } \\
\text { finansowa i źródla } \\
\text { finansowania }\end{array}$ & $\begin{array}{l}\text { Specyficzny typ } \\
\text { gospodarki } \\
\text { finansowej. Jej } \\
\text { podstawę w fazie } \\
\text { założycielskiej } \\
\text { stanowią oszczędności } \\
\text { przedsiębiorcy- } \\
\text { właściciela oraz jego } \\
\text { rodziny, a także } \\
\text { ewentualne pożyczki } \\
\text { od rodziny lub } \\
\text { znajomych. W } \\
\text { dalszych etapach } \\
\text { rozwoju małych firm } \\
\text { zauważa się dążenie } \\
\text { do finansowania ze } \\
\text { środków kapitału } \\
\text { własnego, głównie } \\
\text { z zysku } \\
\text { zatrzymanego. Wiąże } \\
\text { się to z niechęcią do } \\
\text { finansowania działań } \\
\text { firmy kapitałem } \\
\text { obcym (postawę tę } \\
\text { określa się mianem } \\
\text { zjawiska mentalności } \\
\text { kredytowej właścicieli }\end{array}$ & $\begin{array}{l}\text { Firmom sektora trudno } \\
\text { pozyskać środki na } \\
\text { badania spoza sfery } \\
\text { publicznej ze względu na } \\
\text { dhugotrwały proces } \\
\text { i niepewność } \\
\text { prowadzonych badań. Ich } \\
\text { inwestycje są } \\
\text { długofalowe i obarczone } \\
\text { dużym ryzykiem, stąd } \\
\text { firmy często przeznaczają } \\
\text { na rozwój wolne środki } \\
\text { pozostające w ich } \\
\text { dyspozycji. } \\
\text { Inwestycje w sektorze } \\
\text { uznawanym przez rząd za } \\
\text { priorytetowy } \\
\text { wspomagane są przez } \\
\text { liczne zachęty } \\
\text { inwestycyjne, granty } \\
\text { rządowe i fundusze } \\
\text { unijne, np. Program } \\
\text { Operacyjny Innowacyjna } \\
\text { Gospodarka, Program } \\
\text { Operacyjny Kapitał } \\
\text { Ludzki oraz poszczególne }\end{array}$ & $\begin{array}{l}\text { Możliwość } \\
\text { wsparcia dzialań } \\
\text { rozwojowych ze } \\
\text { środków } \\
\text { publicznych i UE }\end{array}$ \\
\hline
\end{tabular}




\begin{tabular}{|c|c|c|c|}
\hline $\begin{array}{l}\text { Struktura } \\
\text { organizacyjna }\end{array}$ & $\begin{array}{l}\text { Uproszczona i często } \\
\text { nisko sformalizowana } \\
\text { struktura } \\
\text { organizacyjna } \\
\text { o podwyższonej } \\
\text { elastyczności } \\
\text { działania, w której } \\
\text { dominują więzi } \\
\text { liniowe. } \\
\text { Charakteryzuje się } \\
\text { stosunkowo małą } \\
\text { liczbą poziomów } \\
\text { hierarchii władzy, } \\
\text { względnie dużymi } \\
\text { jednostkami } \\
\text { roboczymi oraz dużą } \\
\text { rozpiętością } \\
\text { kierowania. Cechą } \\
\text { szczególną jest tu } \\
\text { występowanie } \\
\text { jednego centrum } \\
\text { decyzyjnego, krótka } \\
\text { droga przekazu } \\
\text { informacji, dominacja } \\
\text { szybkiej } \\
\text { i bezpośredniej } \\
\text { komunikacji oraz } \\
\text { ograniczony poziom } \\
\text { delegowania } \\
\text { uprawnień i } \\
\text { odpowiedzialności. }\end{array}$ & $\begin{array}{l}\text { Nisko sformalizowana } \\
\text { struktura organizacyjna } \\
\text { o podwyższonej } \\
\text { elastyczności działania, } \\
\text { często wykorzystująca } \\
\text { potencjał pracy } \\
\text { zespołowej. Wysoka } \\
\text { decentralizacja. } \\
\text { Sieci kooperacyjne } \\
\text { powiązanych jednostek } \\
\text { samozarządzających się, } \\
\text { skoncentrowanych na } \\
\text { procesach. } \\
\text { Samodzielność } \\
\text { i autonomia pracowników } \\
\text { wsparta wiedzą } \\
\text { i wysokimi, często } \\
\text { unikatowymi } \\
\text { kompetencjami. } \\
\text { nieformalna. } \\
\text { technologie } \\
\text { wykormatyczne, pionowa, } \\
\text { infioma, często } \\
\text { somikacja }\end{array}$ & $\begin{array}{l}\text { Elastyczna } \\
\text { struktura } \\
\text { organizacyjna } \\
\text { Bezpośrednia } \\
\text { i szybka } \\
\text { komunikacja }\end{array}$ \\
\hline $\begin{array}{l}\text { Zachowania } \\
\text { rynkowe }\end{array}$ & $\begin{array}{l}\text { Wysoka elastyczność } \\
\text { działania i możliwość } \\
\text { szybkiej reakcji na } \\
\text { zmiany otoczenia, co } \\
\text { umożliwia skuteczne } \\
\text { konkurowanie na } \\
\text { rynku nawet } \\
\text { z silniejszymi } \\
\text { podmiotami. Ważną }\end{array}$ & $\begin{array}{l}\text { Duża dynamika rozwoju } \\
\text { sektora, jak i jego firm, } \\
\text { uzależniona z jednej } \\
\text { strony od wielkości } \\
\text { i skuteczności badań (np. } \\
\text { farmaceutyka), z drugiej } \\
\text { zaś od obowiązujących } \\
\text { regulacji prawnych (np. } \\
\text { żywność GMO). }\end{array}$ & $\begin{array}{l}\text { Możliwość } \\
\text { świadczenia usług } \\
\text { i prowadzenia } \\
\text { produkcji zgodnie } \\
\text { z indywidualnymi } \\
\text { potrzebami } \\
\text { klientów }\end{array}$ \\
\hline
\end{tabular}




\begin{tabular}{|c|c|c|c|}
\hline & $\begin{array}{l}\text { cechą staje się tu } \\
\text { również możliwość } \\
\text { świadczenia usług } \\
\text { i prowadzenia } \\
\text { produkcji zgodnie } \\
\text { z indywidualnymi } \\
\text { potrzebami klientów. } \\
\text { Firma potrafi szybko } \\
\text { zareagować na ciągle } \\
\text { zmieniające się } \\
\text { potrzeby klientów, } \\
\text { otwarta jest na } \\
\text { sugestie nowych } \\
\text { rozwiązań, produktów } \\
\text { czy technologii. } \\
\text { Zdolność do } \\
\text { naśladowania } \\
\text { i imitacji produktów. } \\
\text { zbiurokratyzowania } \\
\text { powoduje, że } \\
\text { negocjacje z klientem } \\
\text { są łatwiejsze, a co za } \\
\text { tym idzie, prędzej } \\
\text { dochodzi się do } \\
\text { porozumienia. }\end{array}$ & $\begin{array}{l}\text { Sektor podatny na } \\
\text { cykliczność rozwoju } \\
\text { gospodarki, stąd firmy } \\
\text { muszą być elastyczne, } \\
\text { otwarte na współpracy } \\
\text { międzyorganizacyjnej, by } \\
\text { utrzymać swoją } \\
\text { konkurencyjność } \\
\text { w dłuższej perspektywie. } \\
\text { Nasilona konkurencja } \\
\text { w sektorze skłania do } \\
\text { prowadzenia badań nie } \\
\text { tylko samodzielnie } \\
\text { w firmach, ale i przy } \\
\text { współpracy np. } \\
\text { z uczelniami wyższymi, } \\
\text { parkami } \\
\text { technologicznymi, } \\
\text { w klastrach, przy } \\
\text { wsparciu centrów } \\
\text { innowacji czy } \\
\text { inkubatorów } \\
\text { przedsiębiorczości itp. }\end{array}$ & $\begin{array}{l}\text { Duży dynamizm, } \\
\text { elastyczność } \\
\text { działania }\end{array}$ \\
\hline $\begin{array}{l}\text { Kreatywność } \quad \text { i } \\
\text { motywacja }\end{array}$ & $\begin{array}{l}\text { Małej firmie po prostu } \\
\text { „chce się” działać, } \\
\text { gdyż tworzy ją mały, } \\
\text { zgrany zespół } \\
\text { pracowników. } \\
\text { Pracownicy czują się } \\
\text { w firmie jak } \\
\text { w rodzinie, zależy im } \\
\text { więc na ciągłym } \\
\text { rozwoju i utrzymaniu } \\
\text { firmy. }\end{array}$ & $\begin{array}{l}\text { Ponieważ biotechnologia } \\
\text { to jedna z najbardziej } \\
\text { innowacyjnych dziedzin } \\
\text { gospodarki, więc } \\
\text { w firmach sektora } \\
\text { konieczna jest } \\
\text { wewnętrzna } \\
\text { i międzyorganizacyjna } \\
\text { wymiana informacji, } \\
\text { zdolność i chęć do } \\
\text { uczenia się, } \\
\text { wykorzystywania nowej }\end{array}$ & $\begin{array}{l}\text { Kreatywność, } \\
\text { poszukiwanie } \\
\text { dobrych rozwiązań, } \\
\text { uczenie się } \\
\text { Silna motywacja do } \\
\text { pracy pracowników } \\
\text { i pracodawców }\end{array}$ \\
\hline
\end{tabular}




\begin{tabular}{|c|c|c|c|}
\hline & $\begin{array}{l}\text { Pracownicy generują } \\
\text { pomysły } \\
\text { usprawniające firmę. } \\
\text { Mała firma ma wielką } \\
\text { wolę istnienia, szuka } \\
\text { dobrych rozwiązań dla } \\
\text { siebie, chłonie wiedzę, } \\
\text { obserwuje, walczy. }\end{array}$ & $\begin{array}{l}\text { wiedzy i nowych } \\
\text { technologii. } \\
\text { Wymagane: wysoka } \\
\text { kreatywność personelu, } \\
\text { umiejętność twórczego } \\
\text { myślenia, autonomia, } \\
\text { samodzielność w } \\
\text { rozwiązywaniu } \\
\text { problemów, uczenie się } \\
\text { na błędach, uczenie } \\
\text { zespołowe, podnoszenie } \\
\text { kwalifikacji i rozwój } \\
\text { personelu. }\end{array}$ & \\
\hline $\begin{array}{l}\text { Skala i zakres } \\
\text { dzialania }\end{array}$ & $\begin{array}{l}\text { Prowadzenie } \\
\text { działalności na małą } \\
\text { skalę, w } \\
\text { przeważającej części o } \\
\text { zasięgu lokalnym. } \\
\text { Zredukowane } \\
\text { operacje } \\
\text { administracyjne } \\
\text { i logistyczne. }\end{array}$ & $\begin{array}{l}\text { Liczba podmiotów tego } \\
\text { sektora nie jest duża, } \\
\text { ponieważ sam sektor nie } \\
\text { jest znaczący z punktu } \\
\text { widzenia całej } \\
\text { gospodarki. W krajach } \\
\text { OECD może on osiągnąć } \\
\text { w } 2030 \text { roku poziom } \\
2,7 \% \text { PKB. } \\
\text { Firmy sektora mają } \\
\text { zróżnicowany zakres } \\
\text { oddziaływania, } \\
\text { najczęściej regionalny } \\
\text { i krajowy. }\end{array}$ & - \\
\hline Marketing & $\begin{array}{l}\text { Mała dbałość } \\
\text { o wizerunek firmy, } \\
\text { wynikająca w wielu } \\
\text { przypadkach z braku } \\
\text { wiedzy z zakresu } \\
\text { marketingu. } \\
\text { Brak wizerunku } \\
\quad \text { firmy. } \\
\text { Bezpośredni kontakt } \\
\text { z klientami, }\end{array}$ & $\begin{array}{l}\text { Małe znaczenie marek } \\
\text { w tym sektorze, marka } \\
\text { nie jest elementem } \\
\text { warunkującym sukces - } \\
\text { jest nim technologia. } \\
\text { Ważny jest bezpośredni } \\
\text { kontakt } \\
\text { i zindywidualizowana } \\
\text { oferta. }\end{array}$ & $\begin{array}{l}\text { Bezpośredni } \\
\text { kontakt z klientem } \\
\text { i } \\
\text { zindywidualizowan } \\
\text { a oferta }\end{array}$ \\
\hline
\end{tabular}




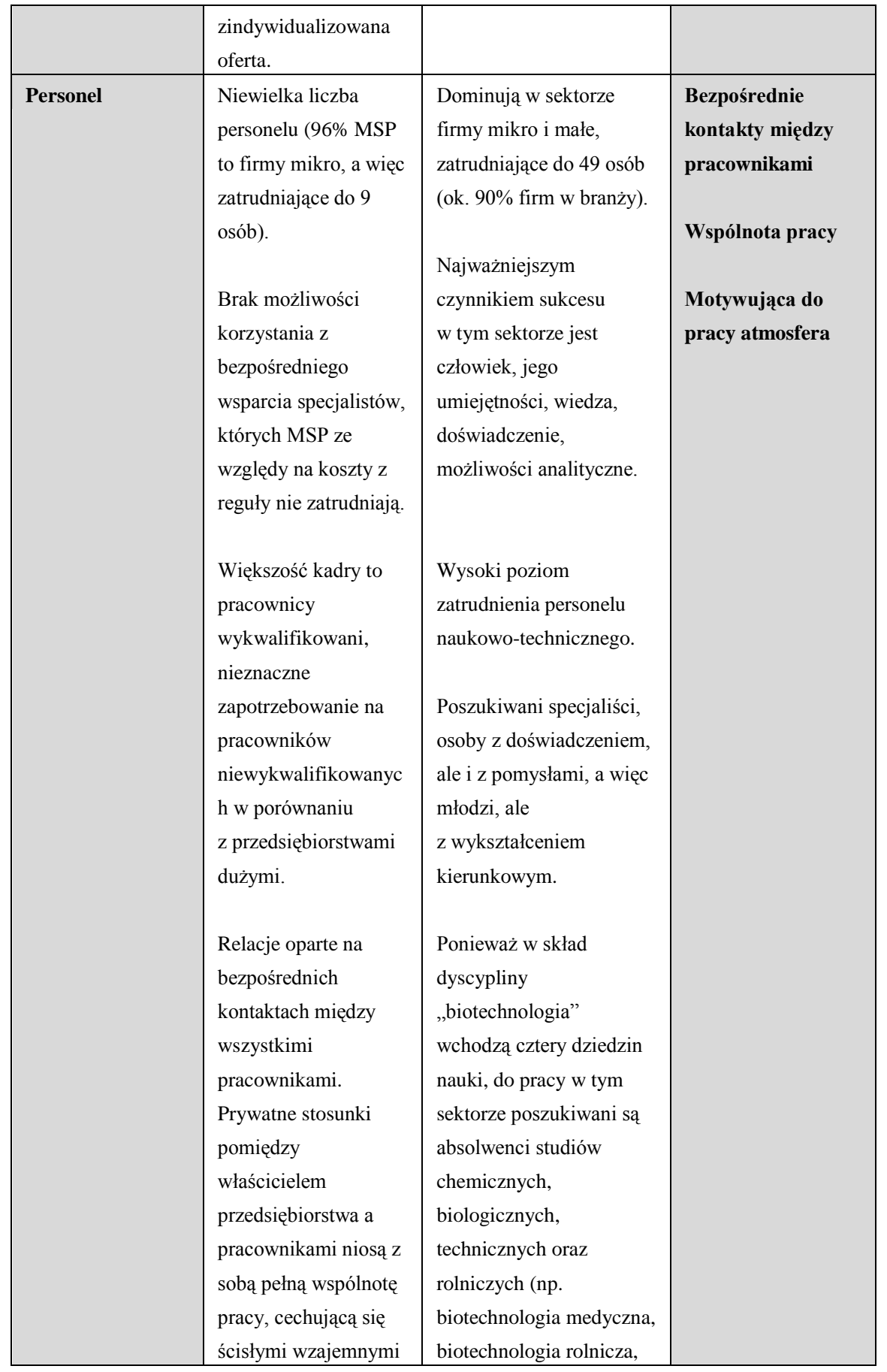




\begin{tabular}{|c|c|c|c|}
\hline & $\begin{array}{l}\text { kontaktami. } \\
\text { Specyficzny system } \\
\text { doboru i } \\
\text { motywowania } \\
\text { personelu, oparty } \\
\text { głównie na } \\
\text { rekomendacjach } \\
\text { i kontaktach } \\
\text { rodzinnych. } \\
\text { Ważnymi } \\
\text { instrumentami } \\
\text { motywowania są tu } \\
\text { nie tylko świadczenia } \\
\text { pieniężne, ale również } \\
\text { odpowiednia } \\
\text { atmosfera pracy - } \\
\text { elastyczna, oparta na } \\
\text { kontaktach } \\
\text { nieformalnych, } \\
\text { bezpośrednich, silnej } \\
\text { integracji z firmą, } \\
\text { rozwiniętej kooperacji } \\
\text { między pracownikami } \\
\text { oraz na dużej } \\
\text { samodzielności } \\
\text { działania personelu. }\end{array}$ & $\begin{array}{l}\text { biotechnologia } \\
\text { środowiskowa, } \\
\text { biotechnologia } \\
\text { przemysłowa). } \\
\text { Poszukiwani są: biolodzy } \\
\text { i pokrewni, tj. biochemik } \\
\text { (213102), biofizyk } \\
\text { (213103), bioinżynier } \\
\text { (213104), biolog } \\
\text { (213105), biotechnolog } \\
\text { (213106), genetyk } \\
\text { (213107), mikrobiolog } \\
\text { (213108). Istotne są także } \\
\text { takie zawody, jak: } \\
\text { inżynier biocybernetyki } \\
\text { i inżynierii biomedycznej, } \\
\text { zawody lekarskie takie, } \\
\text { jak lekarz genetyki } \\
\text { klinicznej, mikrobiologii } \\
\text { lekarskiej, diagnosta } \\
\text { laboratoryjny czy też } \\
\text { farmaceuta } \\
\text { w zakresie mikrobiologii } \\
\text { i biotechnologii. }\end{array}$ & \\
\hline Koszty & $\begin{array}{l}\text { Realizacja inwestycji } \\
\text { sposobem } \\
\text { gospodarczym, } \\
\text { znacznie obniżającym } \\
\text { koszty. } \\
\text { Ze względu na małą } \\
\text { ekonomię skali } \\
\text { wyższy jest koszt } \\
\text { jednostkowy } \\
\text { wytworzenia } \\
\text { produktu, }\end{array}$ & $\begin{array}{l}\text { Wysokie koszty stałe ze } \\
\text { względu na wysokie } \\
\text { koszty prowadzenia } \\
\text { badań, ochrony własności } \\
\text { intelektualnej } \\
\text { wieloletnich prac, } \\
\text { zabezpieczenia z nich } \\
\text { renty oraz } \\
\text { komercjalizacji. }\end{array}$ & $\begin{array}{l}\text { Realizacja } \\
\text { inwestycji } \\
\text { sposobem } \\
\text { gospodarczym, } \\
\text { znacznie } \\
\text { obniżającym koszty }\end{array}$ \\
\hline
\end{tabular}




\begin{tabular}{|c|c|c|c|}
\hline & $\begin{array}{l}\text { przekładający się } \\
\text { następnie na } \\
\text { ograniczony zysk } \\
\text { małej i średniej firmy. } \\
\text { Mniejsza masa } \\
\text { wypracowanego } \\
\text { zysku ogranicza z } \\
\text { kolei możliwości } \\
\text { powiększania kapitału } \\
\text { własnego, wyznacza } \\
\text { niższą wiarygodność } \\
\text { kredytową i zawęża } \\
\text { granice dostępu MSP } \\
\text { do kredytu } \\
\text { bankowego i innych } \\
\text { form finansowania } \\
\text { obcego w porównaniu } \\
\text { z dużymi } \\
\text { przedsiębiorstwami. }\end{array}$ & & \\
\hline Skala produkcji & $\begin{array}{l}\text { Trudności w dostępie } \\
\text { do efektów skali } \\
\text { produkcji (na których } \\
\text { z kolei opiera się } \\
\text { specyfika dużych } \\
\text { przedsiębiorstw). }\end{array}$ & $\begin{array}{l}\text { Konieczna produkcja na } \\
\text { skalę masową, by zyskać } \\
\text { ekonomikę skali } \\
\text { pozwalającą na obniżenie } \\
\text { kosztu finalnego } \\
\text { produktu, wysokiego ze } \\
\text { względu na ryzykowne, } \\
\text { kosztowne i długotrwałe } \\
\text { badania, do poziomu } \\
\text { akceptowalnego przez } \\
\text { klientów. }\end{array}$ & - \\
\hline $\begin{array}{l}\text { Proces } \\
\text { produkcyjny }\end{array}$ & $\begin{array}{l}\text { Niewielkie know- } \\
\text { how. } \\
\text { Zazwyczaj produkcja } \\
\text { pracochłonna, } \\
\text { a nakłady kapitału } \\
\text { niskie. } \\
\text { W proces produkcyjny } \\
\text { zaangażowane są } \\
\text { urządzenia i maszyny }\end{array}$ & $\begin{array}{l}\text { Stosowanie technik } \\
\text { pracochłonnych, } \\
\text { w których ważny jest } \\
\text { człowiek oraz uzbrojenie } \\
\text { stanowiska (aparatura, } \\
\text { odczynniki, surowce, } \\
\text { materiały, prawa, patenty, } \\
\text { licencje). }\end{array}$ & $\begin{array}{l}\text { Stosowanie } \\
\text { pracochlonnych } \\
\text { technik, w których } \\
\text { ważny jest człowiek }\end{array}$ \\
\hline
\end{tabular}




\begin{tabular}{|c|c|c|c|}
\hline & $\begin{array}{l}\text { uniwersalne. } \\
\text { Umożliwia to szybkie } \\
\text { dostosowanie } \\
\text { wytwarzanych } \\
\text { produktów bądź } \\
\text { świadczonych usług } \\
\text { do potrzeb klienta. }\end{array}$ & $\begin{array}{l}\text { Niezbędne } \\
\text { specjalistyczne know- } \\
\text { how oraz specjaliści. } \\
\text { Szybki proces } \\
\text { „dewaluacji” } \\
\text { opracowywanych } \\
\text { i stosowanych } \\
\text { technologii. }\end{array}$ & \\
\hline $\begin{array}{l}\text { Dzialalność } \\
\text { badawczo- } \\
\text { rozwojowa }\end{array}$ & $\begin{array}{l}\text { Działania w sferze } \\
\text { B+R wypływają } \\
\text { zazwyczaj z } \\
\text { konieczności stałego } \\
\text { dopasowania } \\
\text { produkcji do potrzeb } \\
\text { konsumentów. } \\
\text { Brak stałych, } \\
\text { wyodrębnionych } \\
\text { działów B+R. } \\
\text { Badania naukowe } \\
\text { krótkoterminowe, } \\
\text { oparte niejednokrotnie } \\
\text { na intuicji, brak badań } \\
\text { podstawowych. } \\
\text { Rozón produktów } \\
\text { i nabywania } \\
\text { umiejętności. } \\
\text { i nowych technologii, } \\
\text { wyłącznie na potrzeby } \\
\text { konsumentów. }\end{array}$ & $\begin{array}{l}\text { Jedna z bardziej } \\
\text { naukochłonnych branż, } \\
\text { więc często } \\
\text { wyodrębnione są komórki } \\
\text { B+R. } \\
\text { Wysoki potencjał } \\
\text { współpracy, najczęściej } \\
\text { w zakresie badań, } \\
\text { wymiana informacji, } \\
\text { zdolność do uczenia się, } \\
\text { wykorzystywania nowej } \\
\text { wiedzy i nowych } \\
\text { technologii. } \\
\text { Ceniona współpraca } \\
\text { z różnego typu } \\
\text { organizacjami naukowo- } \\
\text { badawczym bądź } \\
\text { wspierającymi } \\
\text { komercjalizację } \\
\text { rozwiązań. }\end{array}$ & $\begin{array}{l}\text { Rozwój produktów } \\
\text { i nowych } \\
\text { technologii } \\
\text { zorientowany na } \\
\text { potrzeby } \\
\text { konsumentów } \\
\text { Zdolność do } \\
\text { szybkiego uczenia } \\
\text { się i nabywania } \\
\text { umiejętności }\end{array}$ \\
\hline Udzial w rynku & $\begin{array}{l}\text { Względnie mały } \\
\text { udział w rynku, oparty } \\
\text { głównie na }\end{array}$ & $\begin{array}{l}\text { Rynek rozwojowy, } \\
\text { wysoce innowacyjny, } \\
\text { więc takie też powinny }\end{array}$ & - \\
\hline
\end{tabular}




\begin{tabular}{|c|c|c|}
\hline . & $\begin{array}{l}\text { działalności na rynku } \\
\text { lokalnym lub } \\
\text { regionalnym. } \\
\text { Działalność małych } \\
\text { lub średnich firm jest } \\
\text { często związana } \\
\text { z jednym produktem } \\
\text { lub mało } \\
\text { zdywersyfikowana. }\end{array}$ & $\begin{array}{l}\text { być przedsiębiorstwa i ich } \\
\text { produkty (szeroka gama } \\
\text { systematycznie } \\
\text { rozwijanych produktów). } \\
\text { Małe udziały w rynku ze } \\
\text { względu na unikatowość } \\
\text { produktów. } \\
\text { Różne oddziaływanie } \\
\text { produktów branży na } \\
\text { rynek, gdyż liczba } \\
\text { i zróżnicowanie } \\
\text { produktów sektora jest } \\
\text { bardzo duże. Inne } \\
\text { oddziaływanie mają } \\
\text { produkty roślinne, inne } \\
\text { dotyczące zwierząt, } \\
\text { środków czystości, } \\
\text { artykułów } \\
\text { przemysłowych czy } \\
\text { leków } \\
\text { i farmaceutyków. Mają } \\
\text { one tylko jedną wspólną } \\
\text { cechę: powstały w } \\
\text { wyniku operowania na } \\
\text { żywych komórkach, przez } \\
\text { wprowadzenie zmian w } \\
\text { ich strukturze } \\
\text { genetycznej. }\end{array}$ \\
\hline
\end{tabular}




\begin{tabular}{|c|c|c|c|}
\hline $\begin{array}{l}\text { Relacje } \\
\text { z otoczeniem, } \\
\text { współpraca }\end{array}$ & $\begin{array}{l}\text { Sieć osobistych } \\
\text { kontaktów } \\
\text { z kontrahentami oraz } \\
\text { względna otwartość } \\
\text { na otoczenie } \\
\text { (porowatość } \\
\text { organizacji). } \\
\text { Małe firmy wchodzą } \\
\text { często w bliskie } \\
\text { kontakty z wąskim } \\
\text { kręgiem dostawców } \\
\text { i odbiorców, } \\
\text { eliminując } \\
\text { anonimowość } \\
\text { i wytwarzając } \\
\text { korzystne relacje } \\
\text { współdziałania. } \\
\text { Problemy } \\
\text { komunikacyjne } \\
\text { pomiędzy firmami, } \\
\text { wynikające z różnicy } \\
\text { w wielkości firm oraz } \\
\text { z różnic kulturowych. } \\
\text { Brak tendencji do } \\
\text { organizowania się } \\
\text { w lokalne grupy, } \\
\text { obrony swoich } \\
\text { interesów. } \\
\text { Brak trwałych } \\
\text { powiązań z innymi } \\
\text { podmiotami. }\end{array}$ & 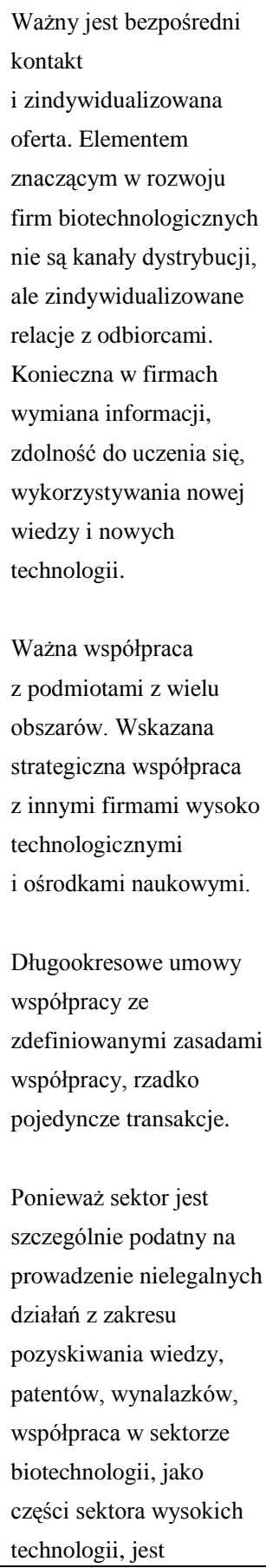 & $\begin{array}{l}\text { Bliskie kontakty } \\
\text { z dostawcami } \\
\text { i odbiorcami } \\
\text { Otwartość na } \\
\text { otoczenie }\end{array}$ \\
\hline
\end{tabular}




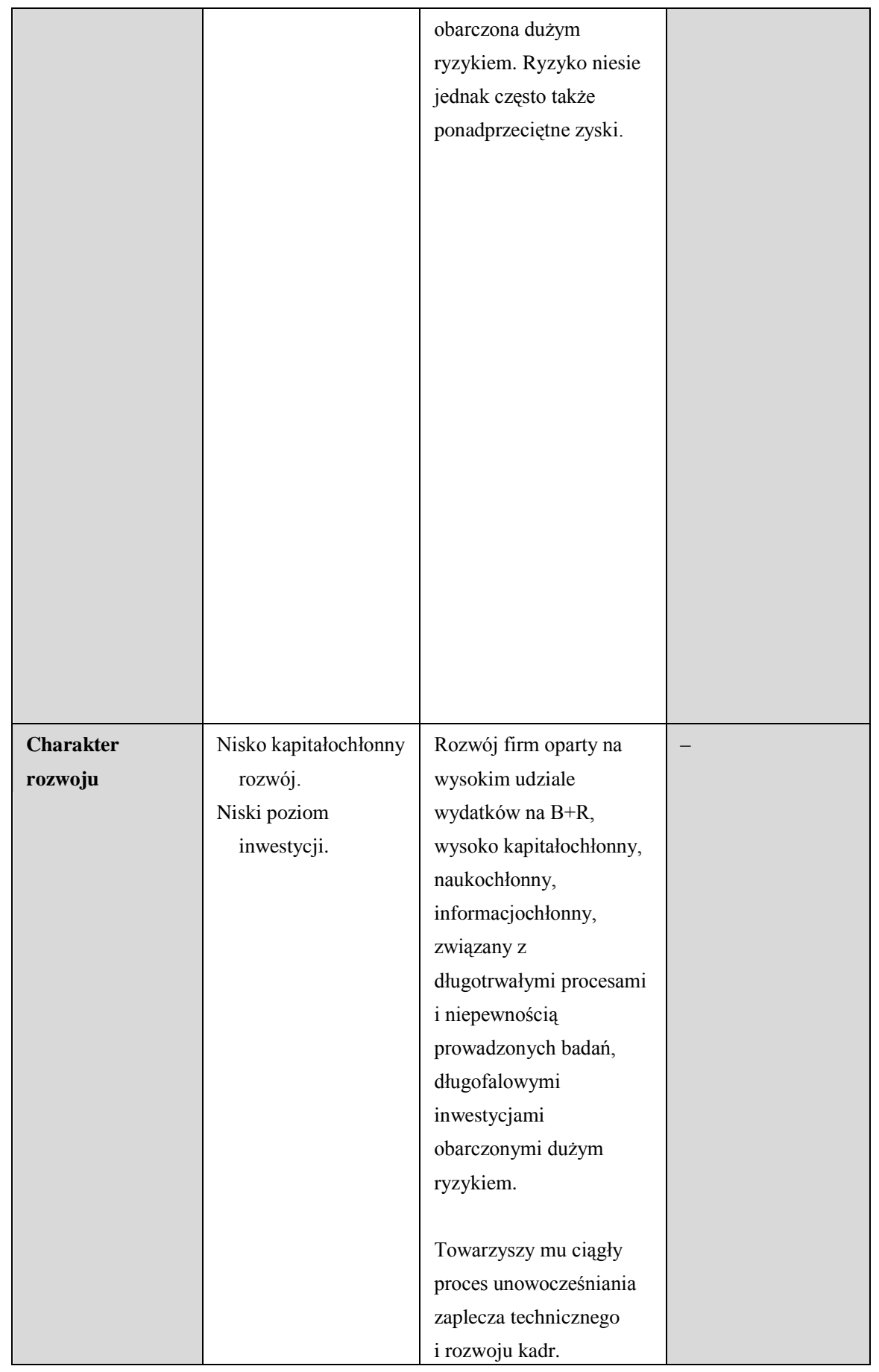




\begin{tabular}{|l|l|l|l|}
\hline Eksport & $\begin{array}{l}\text { Śladowy udział } \\
\text { eksportu. }\end{array}$ & Zróżnicowany & - \\
& & w zależności od branży, & \\
& ale wciąż mały. Mała & \\
& znajomość polskich & \\
& marek na rynkach & \\
& międzynarodowych. & \\
& Dominacja produktów & \\
& z USA. & \\
\hline
\end{tabular}

Źródło: opracowanie własne.

Dokonana analiza wskazuje, że dość dużo cech specyficznych dla MSP sprzyja rozwojowi przedsiębiorstw branży biotechnologicznej. $\mathrm{Na}$ dziewiętnaście badanych cech jedenaście wykazuje symptomy pozytywnego wpływu. Dużym wsparciem jest z pewnością doświadczenie, osobowość, wykształcenie kierunkowe, a zwłaszcza pasja osób kierujących małymi firmami biotechnologicznymi. Cenne są też bezpośrednie relacje z partnerami, kształtowane zarówno w układach wewnątrz-, jak i międzyorganizacyjnych, otwartość na otoczenie, chęć ciągłego uczenia się, motywacja do dynamicznego rozwoju, kreatywność i elastyczność w działaniu. Zachowania te należy pielęgnować i pogłębiać, gdyż sprzyjają tak pożądanej w biotechnologii, szerokopłaszczyznowej innowacyjności. To one będą w przyszłości inicjowały i dynamizowały ich dalszy rozwój.

Warto jednocześnie zaznaczyć, że firmy biotechnologiczne dość dobitnie odczuwają negatywne konsekwencje towarzyszącej zwykle małym firmom luki zasobowej. Ograniczone zasoby materialne i niematerialne to w praktyce często niewystarczające inwestycje w wyposażenie, aparaturę, brak własnego, innowacyjnego know-how, zbyt mała liczba specjalistów, a $\mathrm{w}$ efekcie niewielka skala produkcji i działania, wciąż mały udział w rynku, ograniczona siła i wiarygodność rynkowa.

Nadzwyczaj istotne dla firm biotechnologicznych okazują się $\mathrm{w}$ powyższej sytuacji zachowania związane $\mathrm{z}$ nawiązywaniem bliskich, partnerskich relacji współpracy $\mathrm{z}$ różnymi elementami otoczenia. Minimalizując braki, przełamują one nie tylko lukę zasobową, ale także wzmacniają skalę działania i rozwijają poprzez partnerstwo wiedzy (knowledge partnering) potencjał innowacyjności firm biotechnologicznych [Adamik, Flaszewska, 2013]. Szczególnie cenne wydaje się wsparcie ze strony uczelni wyższych, organizacji naukowo-badawczych, aniołów biznesu, organizacji branżowych. Warto walczyć także o zasilenia $\mathrm{z}$ budżetu państwa, UE czy od władz lokalnych. 


\section{MSP branży biotechnologicznej - źródla sukcesów na przykładzie wybranych przypadków}

Aby zweryfikować na konkretnych przypadkach poprawność powyższych wniosków, syntetycznej analizie poddano historię i funkcjonowanie dwóch łódzkich małych firm biotechnologicznych: BTL Sp. z o.o. oraz TriMen Chemicals S.A. W tabeli 2 zebrano informacje o wybranych do porównań firmach i prześledzono na ich przykładach specyfikę oraz rolę źródeł sukcesu zidentyfikowanych dla małych firm biotechnologicznych.

Tabela 2. Zestawienie źródeł sukcesu firm BTL Sp. z o.o i TriMen Chemicals S.A.

\begin{tabular}{|c|c|c|}
\hline Parametry & BTL Sp. z o.o. ${ }^{19}$ & TriMen Chemicals S.A. ${ }^{20}$ \\
\hline $\begin{array}{l}\text { Krótka historia } \\
\text { i charakterystyka } \\
\text { firmy }\end{array}$ & $\begin{array}{l}\text { Powstała w Łodzi w } 1990 \text { r. } \\
\text { spółka to pierwszy i jedyny w } \\
\text { Polsce zakład produkcji } \\
\text { enzymów i peptonów, który } \\
\text { wprowadza na rynek nowe } \\
\text { produkty do identyfikacji } \\
\text { drobnoustrojów } \\
\text { i kontroli czystości } \\
\text { mikrobiologicznej, głównie dla } \\
\text { przemysłu spożywczego } \\
\text { i farmaceutycznego, laboratoriów } \\
\text { medycznych i badawczych oraz } \\
\text { instytucji epidemiologicznych } \\
\text { i weterynaryjnych. Firma } \\
\text { specjalizuje się w następujących } \\
\text { dziedzinach: wytwarzanie } \\
\text { bioproduktów, analizy } \\
\text { biochemiczne, dystrybucja } \\
\text { odczynników, doradztwo }\end{array}$ & $\begin{array}{l}\text { Firma powstała w } 1998 \text { r. w Łodzi. } \\
\text { Jest firmą badawczo-rozwojową, } \\
\text { prowadzącą badania w zakresie } \\
\text { chemii medycznej, świadczy też } \\
\text { usługi syntetyczne i analityczne } \\
\text { dla firm biochemicznych, } \\
\text { biotechnologicznych, } \\
\text { farmaceutycznych oraz } \\
\text { produkcyjnych w Polsce i na } \\
\text { świecie. Firma została założona } \\
\text { przez trzech chemików- } \\
\text { naukowców. Do jej rozwoju } \\
\text { przyczyniła się pasja, wiedza oraz } \\
\text { wytrwałość założycieli firmy. } \\
\text { Obecnie firma zatrudnia } \\
\text { kilkadziesiąt osób. Firma posiada } \\
\text { Certyfikat Wiarygodności } \\
\text { Biznesowej - prestiżowe } \\
\text { wyróżnienie nadawane przez Dun }\end{array}$ \\
\hline
\end{tabular}

19 Opracowano na podstawie materiałów udostępnionych przez firmę, informacji zamieszczonych na stronie firmowej www.btl.com.pl oraz wywiadu red. Ł. Gąsiorowskiego $\mathrm{z}$ prezes firmy $\mathrm{H}$. Bednarska, zamieszczonego na łamach biotechnologia.pl (data dostępu 17.03.2013).

20 Opracowano na podstawie materiałów udostępnionych przez firmę, informacji zamieszczonych na stronie firmowej www.trimen.pl oraz wywiadu red. B. Majdy $\mathrm{z}$ wiceprezesem firmy P. Pilaszkiem, zamieszczonego na łamach biotechnologia.pl (data dostępu 17.03.2013). 


\begin{tabular}{|c|c|c|}
\hline & $\begin{array}{l}\text { naukowo-techniczne - szkolenia. } \\
\text { Zatrudnia } 19 \text { osób, z czego 70\% } \\
\text { z wykształceniem wyższym. } \\
\text { Firma posiada licencję na } \\
\text { produkcję i sprzedaż produktów } \\
\text { farmaceutycznych oraz } \\
\text { Certyfikat Systemu Zarządzania } \\
\text { Jakością ISO 9000-2001, ISO } \\
\text { 13485. Nagrodzono ją } \\
\text { certyfikatem „Przedsiębiorstwo } \\
\text { Fair Play” za rok 2005 i 2006. } \\
\text { Firma działa też charytatywnie } \\
\text { oraz uczestniczy } \\
\text { i sponsoruje branżowe } \\
\text { konferencje naukowe (np. pani } \\
\text { prezes reprezentowała firmę na } \\
\text { Europejskim Forum } \\
\text { Gospodarczym Łódzkie 2012) }\end{array}$ & $\begin{array}{l}\text { \& Bradstreet Poland, świadczące } \\
\text { o wysokiej ocenie stabilności } \\
\text { firmy, czyli o jej wysokim } \\
\text { poziomie rentowności, zdolności } \\
\text { i płynności finansowej. }\end{array}$ \\
\hline \multicolumn{3}{|c|}{ Źródla sukcesu firmy } \\
\hline $\begin{array}{l}\text { Osoba determinująca } \\
\text { rozwój (jej } \\
\text { doświadczenie, } \\
\text { wykształcenie } \\
\text { kierunkowe, pasja } \\
\text { i wizja) }\end{array}$ & $\begin{array}{l}\text { H. Bednarska, od } 1994 \text { r. prezes } \\
\text { i członek zarządu spółki, } 37 \text { lat } \\
\text { doświadczenia, także w } \\
\text { przemyśle biofarmaceutycznym. } \\
\text { Ukończone studia na Wydziale } \\
\text { Elektrycznym Politechniki } \\
\text { Łódzkiej oraz na Wydziale } \\
\text { Ekonomiczno-Socjologicznym } \\
\text { Uniwersytetu Łódzkiego. }\end{array}$ & $\begin{array}{l}\text { Połączenie sukcesów naukowych } \\
\text { i umiejętności zarządczych trzech } \\
\text { osób: } \\
\text { 1) Jacka Olczaka - prezesa zarządu } \\
\text { firmy od początku jej istnienia, } \\
\text { absolwenta Wydziału } \\
\text { Chemicznego Politechniki } \\
\text { Łódzkiej; w } 1999 \text { r. uzyskał tytuł } \\
\text { doktora nauk chemicznych na tej } \\
\text { uczelni; jest współautorem } \\
\text { dziesięciu publikacji naukowych } \\
\text { z dziedziny chemii organicznej; } \\
\text { w spółce zajmuje się kontaktami } \\
\text { z klientami biznesowymi oraz } \\
\text { bieżącymi zagadnieniami } \\
\text { chemicznymi; } \\
\text { 2) Witolda Mozgi - wiceprezesa } \\
\text { zarządu, współzałożyciela; tytuł } \\
\text { magistra inżyniera uzyskał na } \\
\text { Wydziale Chemicznym } \\
\text { Politechniki Łódzkiej; na tej samej }\end{array}$ \\
\hline
\end{tabular}




\begin{tabular}{|c|c|c|}
\hline & & $\begin{array}{l}\text { uczelni } \\
\text { w Katedrze Informatyki } \\
\text { Stosowanej ukończył } \\
\text { Podyplomowe Studium } \\
\text { Informatyczne; w spółce zajmuje } \\
\text { się zarówno zagadnieniami } \\
\text { chemicznymi, jak } \\
\text { i informatycznymi; } \\
\text { 3) Przemysława Pilaszka - } \\
\text { wiceprezesa zarządu, absolwenta } \\
\text { Wydziału Chemicznego } \\
\text { Politechniki Łódzkiej, uczestnika } \\
\text { szeregu szkoleń i kursów z zakresu } \\
\text { organizacji i zarządzania; posiada } \\
\text { także wieloletnie praktyczne } \\
\text { doświadczenie menedżerskie jako } \\
\text { współwłaściciel i/lub członek } \\
\text { wielu podmiotów; w spółce } \\
\text { zajmuje stanowisko dyrektora } \\
\text { finansowego; prowadzi też sprawy } \\
\text { HR. }\end{array}$ \\
\hline $\begin{array}{l}\text { Wsparcie działań } \\
\text { rozwojowych ze } \\
\text { środków publicznych } \\
\text { i UE }\end{array}$ & $\begin{array}{l}\text { Firma w toku swojego rozwoju } \\
\text { korzystała nie tylko z własnych } \\
\text { nakładów finansowych, ale także } \\
\text { ze środków Unii Europejskiej } \\
\text { (Europejskiego Funduszu } \\
\text { Rozwoju Regionalnego), budżetu } \\
\text { państwa i MNiSW. }\end{array}$ & $\begin{array}{l}\text { W } 2005 \text { roku spółka uzyskała } \\
\text { wsparcie w ramach Programu Unia } \\
\text { dla Przedsiębiorczych (Program } \\
\text { Konkurencyjność), złożyła też } \\
\text { kolejne wnioski o uzyskanie } \\
\text { dofinansowania ze środków } \\
\text { unijnych (w ramach Regionalnego } \\
\text { Programu Operacyjnego } \\
\text { Województwa Łódzkiego na lata } \\
\text { 2007-2013). }\end{array}$ \\
\hline $\begin{array}{l}\text { Elastyczna struktura } \\
\text { organizacyjna } \\
\text { Bezpośrednia, szybka } \\
\text { komunikacja }\end{array}$ & $\begin{array}{l}\text { Prosta struktura organizacyjna. } \\
\text { Szybki przepływ informacji } \\
\text { między pracownikami } \\
\text { a kierownictwem. } \\
\text { Wchodzenie w sieci współpracy } \\
\text { międzyorganizacyjnej. }\end{array}$ & $\begin{array}{l}\text { Elastyczna struktura } \\
\text { organizacyjna. Dobra komunikacja } \\
\text { wewnątrzorganizacyjna. } \\
\text { Wchodzenie w sieci współpracy } \\
\text { outsourcingowej w zakresie chemii } \\
\text { bloków budulcowych, chemii } \\
\text { kombinatoryjnej i chemii } \\
\text { medycznej, a także innej, }\end{array}$ \\
\hline
\end{tabular}




\begin{tabular}{|c|c|c|}
\hline & & $\begin{array}{l}\text { z różnego typu partnerami, np. } \\
\text { z Fluorochem Ltd., czy Tokyo } \\
\text { Chemical Industry Co. Ltd., } \\
\text { których jest przedstawicielem } \\
\text { w Polsce. }\end{array}$ \\
\hline $\begin{array}{l}\text { Świadczenie usług } \\
\text { i prowadzenie } \\
\text { produkcji zgodnie } \\
\text { z indywidualnymi } \\
\text { potrzebami klientów } \\
\text { Dynamizm rozwoju, } \\
\text { elastyczność dzialania }\end{array}$ & $\begin{array}{l}\text { Odpowiednie wyposażenie } \\
\text { laboratorium, ciągłe inwestycje } \\
\text { w nowe urządzenia } \\
\text { i wykwalifikowany personel } \\
\text { pozwalają na działalność } \\
\text { usługową w dziedzinie } \\
\text { mikrobiologii, zgodną } \\
\text { z indywidualnymi potrzebami } \\
\text { klientów, wysokiej jakości, } \\
\text { dzięki monitoringowi procesów. } \\
\text { Firma wychodzi naprzeciw } \\
\text { oczekiwaniom klientów } \\
\text { i wprowadza systematycznie } \\
\text { nowe produkty do swojej oferty. }\end{array}$ & $\begin{array}{l}\text { Ponad 13-letnie doświadczenie, } \\
\text { utalentowany zespół } \\
\text { kilkudziesięciu chemików } \\
\text { i analityków oraz zaplecze } \\
\text { technologiczne pozwala firmie } \\
\text { zarządzać nawet najbardziej } \\
\text { złożonymi zleceniami syntezy } \\
\text { organicznej i/lub analizy } \\
\text { chemicznej. } \\
\text { Wśród klientów firmy znajdują się } \\
\text { firmy z Polski oraz z zagranicy. } \\
\text { Firma systematycznie rozwija } \\
\text { posiadane laboratorium, inwestując } \\
\text { pozyskane środki UE. }\end{array}$ \\
\hline $\begin{array}{l}\text { Kreatywność, } \\
\text { poszukiwanie } \\
\text { dobrych rozwiązań, } \\
\text { uczenie się }\end{array}$ & $\begin{array}{l}\text { Firma „lubi” zatrudniać } \\
\text { absolwentów zaraz po studiach, } \\
\text { gdy są „naładowani” wiedzą } \\
\text { i pełni energii. } \\
\text { Współpraca z uczelniami } \\
\text { wyższymi i organizacjami } \\
\text { naukowo-badawczymi. }\end{array}$ & $\begin{array}{l}\text { Firma korzysta ze współpracy } \\
\text { z położonymi w regionie dwoma } \\
\text { uniwersytetami i Polską Akademią } \\
\text { Nauk, przez co zapewnia sobie } \\
\text { dostęp do kadry znakomicie } \\
\text { wykształconych i uzdolnionych } \\
\text { chemików oraz specjalistycznej } \\
\text { aparatury analitycznej. }\end{array}$ \\
\hline $\begin{array}{l}\text { Bezpośredni kontakt } \\
\text { z klientem } \\
\text { Zindywidualizowana } \\
\text { oferta }\end{array}$ & $\begin{array}{l}\text { Dzięki bezpośredniemu } \\
\text { kontaktowi z klientem } \\
\text { pracownicy diagnozują potrzeby } \\
\text { rynku, wysuwają innowacyjne } \\
\text { pomysły, które w miarę } \\
\text { możliwości są wdrażane. Dzięki } \\
\text { temu możliwa jest prawie } \\
\text { perfekcyjna obsługa klienta. }\end{array}$ & $\begin{array}{l}\text { Firma buduje w otoczeniu } \\
\text { długotrwałe relacje partnerskie } \\
\text { oparte na zaufaniu, wysokiej } \\
\text { jakości i zrozumieniu potrzeb } \\
\text { partnerów biznesowych. } \\
\text { Nowych klientów najczęściej } \\
\text { pozyskuje na zasadzie polecenia. }\end{array}$ \\
\hline $\begin{array}{l}\text { Relacje oparte na } \\
\text { bezpośrednich } \\
\text { kontaktach między }\end{array}$ & $\begin{array}{l}\text { W firmie panuje „rodzinna” } \\
\text { atmosfera, sprzyjająca pracy } \\
\text { i współpracy, stąd rotacja }\end{array}$ & $\begin{array}{l}\text { Dzięki dobrej współpracy } \\
\text { w zespole pracowników firma } \\
\text { wypracowała standardy regulujące }\end{array}$ \\
\hline
\end{tabular}




\begin{tabular}{|c|c|c|}
\hline $\begin{array}{l}\text { wszystkimi } \\
\text { pracownikami } \\
\text { Motywująca do pracy } \\
\text { atmosfera }\end{array}$ & $\begin{array}{l}\text { pracowników jest niewielka. } \\
\text { Innowacyjne pomysły zgłaszane } \\
\text { przez pracowników są } \\
\text { analizowane i w miarę } \\
\text { możliwości wdrażane. } \\
\text { Źródłem innowacyjności są } \\
\text { dzięki temu sami pracownicy, co } \\
\text { pobudza ich motywację do } \\
\text { działania. }\end{array}$ & $\begin{array}{l}\text { podział projektu na etapy, } \\
\text { zarządzanie grupą chemików, } \\
\text { kontrolę jakości procesów } \\
\text { syntezy/analizy, prowadzenie } \\
\text { dokumentacji na każdym etapie } \\
\text { projektu (lub zlecenia), } \\
\text { zapewnienie bezpieczeństwa } \\
\text { i poufności danych oraz } \\
\text { przygotowanie raportu } \\
\text { zakończenia projektu. W efekcie } \\
\text { zyskano wysoką jakość, } \\
\text { terminowość wykonania } \\
\text { i bezpieczeństwo dostawy } \\
\text { produktów. } \\
\text { Sprawdzające się w działaniu } \\
\text { zasady pracy wspierają motywację. }\end{array}$ \\
\hline $\begin{array}{l}\text { Stosowanie technik } \\
\text { pracochlonnych, } \\
\text { w których ważny jest } \\
\text { człowiek }\end{array}$ & $\begin{array}{l}\text { W firmie pracuje } \\
\text { wykwalifikowany personel } \\
\text { posiadający wiedzę } \\
\text { mikrobiologiczną, } \\
\text { przestrzegający zasad } \\
\text { bezpieczeństwa przy pracy } \\
\text { z substancjami uznanymi za } \\
\text { niebezpieczne. }\end{array}$ & $\begin{array}{l}\text { W firmie pracuje kadra znakomicie } \\
\text { wykształconych i uzdolnionych } \\
\text { chemików wykorzystujących } \\
\text { specjalistyczną aparaturę } \\
\text { analityczną. }\end{array}$ \\
\hline $\begin{array}{l}\text { Zdolność do } \\
\text { szybkiego uczenia się } \\
\text { i nabywania } \\
\text { umiejętności }\end{array}$ & $\begin{array}{l}\text { Od } 2004 \text { r. firma należy do } \\
\text { łódzkiego klastra BioTechMed, } \\
\text { powstałego na bazie Centrum } \\
\text { Zaawansowanych Technologii } \\
\text { BioTechMed, finansowanego w } \\
\text { początkowej fazie ze środków } \\
\text { MNiSW. Dzięki temu ma szanse } \\
\text { współpracować z jego } \\
\text { założycielami - m.in. } \\
\text { Politechniką Łódzką, } \\
\text { Uniwersytetem Łódzkim, } \\
\text { Łódzkim Uniwersytetem } \\
\text { Medycznym, Centrum Badań } \\
\text { Molekularnych i } \\
\text { Makromolekularnych PAN, }\end{array}$ & $\begin{array}{l}\text { Firma uczestniczy w różnego typu } \\
\text { branżowych, zarówno krajowych, } \\
\text { jak i zagranicznych, targach (np. } \\
\text { Targi EuroLab 2012) } \\
\text { i konferencjach naukowych (np. } \\
\text { BIO-EUROPE } 2011 \\
\text { w Duesseldorfie, Niemcy). } \\
\text { Współpracuje także z wieloma } \\
\text { uczelniami (np. UŁ, PŁ, } \\
\text { Uniwersytet Medyczny w Łodzi) } \\
\text { oraz partnerami biznesowymi, } \\
\text { zarówno krajowymi, jak } \\
\text { i zagranicznymi - np. Tokyo } \\
\text { Chemical Industry Co. Ltd. (TCI), }\end{array}$ \\
\hline
\end{tabular}




\begin{tabular}{|c|c|c|}
\hline & $\begin{array}{l}\text { Instytutem Biologii Medycznej } \\
\text { PAN, Instytutem Medycyny } \\
\text { Pracy w Łodzi, a także innymi } \\
\text { podmiotami skupionymi } \\
\text { w klastrze - np. Polfamex S.A., } \\
\text { IFOTAM Sp. z o.o., Pharmena } \\
\text { Sp. z o.o., ICHEM Sp. z o.o., } \\
\text { HURTAP S.A itp., a także } \\
\text { z innymi partnerami - np. } \\
\text { Instytutem Biotechnologii } \\
\text { Przemysłu Rolno-Spożywczego } \\
\text { w Łodzi (wykonawca prac } \\
\text { badawczych). }\end{array}$ & Fluorochem. \\
\hline $\begin{array}{l}\text { Otwartość na } \\
\text { otoczenie }\end{array}$ & $\begin{array}{l}\text { Współpraca z łódzkimi } \\
\text { uczelniami oraz ośrodkami } \\
\text { badawczo-rozwojowymi } \\
\text { z całego kraju pozwoliła na } \\
\text { ukierunkowanie } \\
\text { mikrobiologicznego profilu } \\
\text { zakładu. }\end{array}$ & $\begin{array}{l}\text { Firma jest otwarta na różnych } \\
\text { partnerów, nie jest nastawiona } \\
\text { wyłącznie na NewConnect. Jeżeli } \\
\text { znajdzie się inwestor prywatny lub } \\
\text { fundusz kapitałowy, to zamierza } \\
\text { podjąć z nim współpracę. Nie ma } \\
\text { także jednego wyznaczonego pola } \\
\text { działania. To, w którą stronę } \\
\text { pójdzie, uzależnione jest od } \\
\text { wymagań tych, którzy będą chcieli } \\
\text { ją sfinansować. Jeżeli jakiś } \\
\text { fundusz zechce sfinansować } \\
\text { rozwój innowacji, firma zamierza } \\
\text { silnie pracować nad działem R\&D. } \\
\text { Jeśli prywatny inwestor } \\
\text { zainteresuje się działalnością } \\
\text { usługową, będzie to dla niej nowy } \\
\text { priorytet. }\end{array}$ \\
\hline
\end{tabular}

Źródło: opracowanie własne.

Wydaje się, że przypadki firm BTL Sp. z o.o. oraz TriMen Chemicals S.A. dość wyraźnie potwierdzają, że przeprowadzone analizy profili typowego dla MSP oraz typowego dla firm biotechnologicznych zasygnalizowały rzeczywiste źródła sukcesów i problemów polskich firm biotechnologicznych. W każdej z badanych firm dość jasno zarysowane są, wynikające $\mathrm{z}$ zestawienia $\mathrm{w}$ tabeli 1 , źródła sukcesu charakterystyczne dla 
małych firm biotechnologicznych. Do analizowanych firm można więc odnieść rekomendacje zbieżne dla profilu branży.

\section{Konkluzje}

Dokonana w artykule identyfikacja kluczowych parametrów oraz źródeł skuteczności polskich firm biotechnologicznych wydaje się logiczna, spójna i znajduje uzasadnienie w praktyce gospodarczej. Poprawność jej potwierdzają, zbieżne $\mathrm{z}$ uzyskanymi $\mathrm{w}$ pracy, wyniki badań UE nad sukcesem nowych firm wysoko technologicznych z różnych branż (np. biotechnologia, ICT, mikroelektronika), przeprowadzone w 2000 r. Zgodnie $\mathrm{z}$ nimi $\mathrm{w}$ analizowanej branży najważniejszymi czynnikami sukcesu były: wiedza założycieli, relacje z głównymi klientami, jakość kapitału ludzkiego, wsparcie ze strony funduszy wysokiego ryzyka oraz oparcie zarządzania na wizji i poczuciu wspólnego celu. Na plan pierwszy wysuwało się jednocześnie zarządzanie oparte na płaskich strukturach, polityce „otwartych” drzwi, kładące nacisk na szkolenie oraz rozwój sieci interpersonalnych, maksymalizujących: ścisłe skupienie się na określonym rynku i produkcie, współpracę z innymi firmami, orientację na klienta, ostrożne zarządzanie finansami oraz nacisk na ludzi jako źródła wzrostu. Poza tym okazało się, że czynnikiem sukcesu w branży częściej był też kapitał ludzki niż zasoby techniczne czy finansowe [Wojnicka, 2006]. Również badania firm innowacyjnych przeprowadzone w 2005 r. na Uniwersytecie Łódzkim [Stawasz, 2006] sygnalizowały, że za podstawę sukcesów rynkowych i technicznych odpowiedzialne są w ich przypadku związki z jednostkami $B+R$, elastyczność i szybkość działania oraz rozwój kompetencji technicznych.

Dla przyspieszenia rozwoju oraz podniesienia konkurencyjności polskich firm biotechnologicznych wszelkie zmiany w sposobach ich działania powinny iść we wskazanych w artykule kierunkach. Wzmacniać należy stopień wykorzystania zdiagnozowanych źródeł sukcesu, minimalizować zaś zakres oddziaływania czynników utrudniających ich rozwój. W szczególny sposób warto zwrócić uwagę na podniesienie wiedzy kadr kierowniczych firm biotechnologicznych w zakresie zarządzania, zwłaszcza strategicznego. Należy także próbować wszelkimi środkami, także zewnętrznymi, wzmacniać wyposażenie firm zarówno w kapitał finansowy, jak i rzeczowy. Nie powinno się zaniedbywać również inwestowania $\mathrm{w}$ najcenniejszy dla branży kapitał ludzki. Trzeba go wspierać nie tylko poprzez szkolenia, odpowiednie wyposażenie, ale także system motywowania, klimat zaufania, bliskie, partnerskie relacje współpracy, zarówno w poszczególnych zespołach, jak i w układach 
z różnego typu partnerami zewnętrznymi. Wygenerowane dzięki temu partnerstwo wiedzy ma szansę stać się długookresowym, a przy tym kluczowym wsparciem ich skuteczności.

Ze względu na istotne powiązania biotechnologii z innymi naukami, a w praktyce gospodarczej powiązania firm biotechnologicznych z innymi branżami, strategicznym wsparciem ich rozwoju wydają się także działania władz centralnych i samorządowych. Wśród najbardziej pożądanych wskazuje się na ich pomoc przy [Skawińska, Zalewski, 2009]:

1) tworzeniu silnej bazy naukowej $w$ postaci podstawowych, stosowanych

i klinicznych badań naukowych,

2) tworzeniu wysokiej kultury przedsiębiorczości w środowisku naukowym i akademickim,

3) tworzeniu szerokiej bazy przedsiębiorstw, zarówno nowych, jak i dojrzałych firm biotechnologicznych oraz farmaceutycznych,

4) przyciagnięciu utalentowanej kadry naukowej i menedżerskiej z innych przedsiębiorstw, uczelni wyższych oraz ośrodków badawczonaukowych,

5) zwiększeniu dostępności usług okołobiznesowych (usług prawniczych, rzeczników patentowych, doradców ds. własności intelektualnej, doradców personalnych),

6) przyspieszaniu rozwoju i zwiększaniu dostępności zwłaszcza do dużych firm w pokrewnych przemysłach (np. farmaceutycznym, chemicznym, rolno-spożywczym, bioinformatycznym).

W szczególnym stopniu wsparcie to wskazane jest w regionach predysponowanych do efektywnego rozwoju ośrodków i klastrów biotechnologicznych, czyli $\mathrm{w}$ dużych miastach o wysokim potencjale naukowo-badawczym, np. w Krakowie, Gdańsku, Łodzi, Poznaniu, Warszawie czy Wrocławiu.

\section{Referencje}

1. Adamik A., Flaszewska S., Partnerstwo wiedzy jako determinanta działań przedsiębiorczych [w:] S. Lachiewicz, S. Flaszewska, M. Nowicki (red.) Społeczno-organizacyjne czynniki rozwoju przedsiębiorczości, Monografie Politechniki Łódzkiej, Łódź 2013.

2. Adamik A.: Building competitive advantage based on cooperation as the basis for success of SME's in high technology sector, [w:] J. Lewandowski, M. Sekieta (red.) Trends and ideas in 
management, A Series of Monographs, Wydawnictwo Politechniki Łódzkiej, Łódż 2007.

3. Brodzicki T., Uwarunkowania rozwoju nowoczesnych technologii w Gdańsku, IBnGR dla Miasta Gdańska, Gdańsk 2002.

4. Dominiak P., Sektor MSP we wspótczesnej gospodarce, Wydawnictwo Naukowe PWN, Warszawa 2005.

5. Główny Urząd Statystyczny, Nauka i technika w Polsce w 2009 roku, Warszawa, 2011.

6. Janiuk I., Strategiczne dostosowanie polskich matych i średnich przedsiębiorstw do konkurencji europejskiej, Difin, Warszawa 2004.

7. Lachiewicz S., Załęczny L., Małe firmy $w$ gospodarce rynkowej, [w:] Lachiewicz S. (red.), Małe firmy w regionie łódzkim, Wydawnictwo Politechniki Łódzkiej, Łódź 2003.

8. Łuczka T., Kapitat obcy w matym $i$ średnim przedsiębiorstwie. Wybrane aspekty mikro- i makroekonomiczne, Wydawnictwo Naukowe PWN, Warszawa-Poznań 2001.

9. Matejun M. (red) Zarzadzanie mała $i$ średniq firma $w$ teorii i ćwiczeniach, Difin, Warszawa, 2012.

10. Ministerstwo Nauki i Szkolnictwa Wyższego, Stan i kierunki rozwoju biogospodarki, Warszawa, 2007.

11. Nogalski B., J. Karpacz, A. Wójcik-Karpacz, Funkcjonowanie $i$ rozwój matych i średnich przedsiębiorstw. Od czego zależy?, „AIG” sp. z o. o. - Oficyna Wydawnicza, Bydgoszcz 2004.

12. OECD, The Bioecenomy to 2030. Designing a Policy Agenda. Main Findings and Policy Conclusions, Paris 2009.

13. Piasecki B., Mała firma $w$ teoriach ekonomicznych, [w:] Piasecki B. (red.), Ekonomika i zarządzanie małą firmą, Wydawnictwo Naukowe PWN, Warszawa-Łódź 2001.

14. PMR, Pharmaceutical biotechnology in Poland: current conditions and forecasts, 2011.

15. Podlaskie Obserwatorium Rynku Pracy i Prognoz Gospodarczych, Startery Podlaskiej gospodarki. Analiza gospodarczych obszarów wzrostu $i$ innowacji województwa podlaskiego. Sektor biotechnologii, Wojewódzki Urząd Pracy w Białymstoku, Białystok 2011.

16. Safin K. (red.), Zarzadzanie małym i średnim przedsiębiorstwem, Wydawnictwo AE im. O. Langego we Wrocławiu, Wrocław 2008. 
17. Sektor farmaceutyczny i biotechnologiczny w Polsce, Departament Informacji Gospodarczej Polska Agencja Informacji i Inwestycji Zagranicznych S.A., Warszawa 2011.

18. Sektor matych $i$ średnich przedsiębiorstwa $w$ Polsce, Raport Polskiej Agencji Rozwoju Przedsiębiorczości, Warszawa 2012.

19. Skawińska E., Zalewski R.I., Przykłady klastrów w dziedzinie biotechnologii [w:] Skawińska E., Zalewski R.I., Klastry biznesowe w rozwoju konkurencyjności i innowacyjności regionów. Świat, Europa, Polska, PWE, Warszawa 2009.

20. Stawasz E., Charakterystyka i potrzeby firm wysoko innowacyjnych $z$ sektora MSP $w$ regionie tódzkim [w:] L. Lewandowska (red.), Konkurencyjność firm regionu łódzkiego na rynkach międzynarodowych, Polskie Towarzystwo Ekonomiczne Oddział w Łodzi, Łódź 2006.

21. Turowski K., Sektor wysokiej techniki jako glówne źródło wzrostu we wspótczesnej gospodarce światowej [w:] D. Kopycińska( red.) Funkcjonowanie gospodarki polskiej w warunkach integracji i globalizacji, Katedra Ekonomii Uniwersytetu Szczecińskiego, Szczecin 2005.

22. Wasilczuk J.E., Wzrost malych i średnich przedsiębiorstw. Aspekty teoretyczne $i$ badania empiryczne, Wydawnictwo Politechniki Gdańskiej, Gdańsk 2005.

23. Wojnicka E. (red.), Perspektywy rozwoju matych i średnich przedsiębiorstw wysokich technologii w Polsce do 2020r., Polska Agencja Rozwoju Przedsiębiorczości, Warszawa, 2006.

24. Zakrzewska -Bielawska A., Relacje między strategiq a struktura organizacyjnq $w$ przedsiębiorstwach sektora wysokich technologii, Politechnika Łódzka, Zeszyty Naukowe nr 1095, Łódź 2011.

\section{Źródla internetowe}

1. biotechnologia.pl;

2. Ministerstwo dofinansuje aparaturę badawczą, online, protokół dostępu: http://dolinabiotechnologiczna.pl/nowosci/ministerstwodofinansowuje-aparature-badawcza/, data dostępu 4.10.2011;

3. MNiSzW:Biotechnologia

4. Portal Biotechnologia.com

5. Portal dolinabiotechnologiczna.pl,

6. Ustawa refundacyjna spowoduje zapaść krajowego przemysłu, 23.03.2011, online,

protokół dostępu: 
http://www.biotechnologia.com.pl/biotechnologiaportal/info/farma cja/22 aktualnosci/228692,

7. ustawa_refundacyjna_spowoduje_zapasc_krajowego_przemysu_.h tml, data dostępu 22.09.2011;

8. www.btl.com.pl

9. www.trimen.pl

\begin{abstract}
This paper attempts to identify the key parameters and sources of efficiency Polish biotechnology companies. As more than $90 \%$ of them are small and medium-sized the base for analysis is profile characterizing such organizations. In the study was applied SME profile on the profile of biotechnology firm. An overview of these two blocks of information was gave list of main successes and problems sources of biotechnology companies and let to prepare resulting conclusions. To verify the literature analysis by empirical data were described two cases of typical small biotech firm.
\end{abstract}

